\title{
植生開水路流れの組織乱流構造に及ぼす かぶり水深の影響に関する研究
}

\section{EFFECTS OF RELATIVE SUBMERGENCE ON COHERENT TURBULENCE STRUCTURE IN VEGETATED OPEN-CHANNEL FLOW}

\author{
岡本隆明 ${ }^{1}$ ，禰津家久 ${ }^{2}$, 山上路生 ${ }^{3}$ \\ Takaaki Okamoto and Iehisa Nezu and Michio Sanjou \\ 1学生員, 京都大学大学院修士課程, 工学研究科社会基盤工学専攻（干615-8540 京都市西京区京都大学桂） \\ 2フェロー, 工博, 京都大学大学院教授, 工学研究科社会基盤工学専攻（同上） \\ 3 正会員，博（工），京都大学大学院助教，工学研究科社会基盤工学専攻（同上）
}

\begin{abstract}
It is necessary in river environment and hydraulic engineering to investigate the hydrodynamic properties in vegetated canopy rivers, in which velocity distributions are largely changed in the vertical direction. In particular, the relative submergence, i.e., the ratio of the water depth $H$ to the vegetation height $h$, influences velocity profiles significantly. For example, in high submergence, we can see an outer layer in which a logarithmic layer is formed. Whereas, in low submergence, the flow is directly influenced by the vegetation elements. So, in this study, turbulence measurements were conducted intensively in vegetated open-channel flows by changing the relative submergence, and consequently, mean-flow properties, turbulence structure and coherent motions were revealed and discussed in detail.
\end{abstract}

Key Words : : vegetation canopy, open-channel flow, coherent turbulence motion, PIV

\section{1.はじめに}

近年，水域環境への関心が高まるとともに，河川 植生帯を有する浄化機能や侵食防止機能が注目さ れるようになり, 河川の管理を行っていく上で植生 群落を積極的に保持, 利用していくことが求められ るようになった．植生流れ場では植生層内部と外部 との境界部においてせん断不安定性により sweepや ejectionのような大規模な組織乱流構造が発生し, 溶 存物質などのスカラー輸送に大きな影響を及ぼす ことが示唆される.これまでに植生流れの研究は微 気象学と河川工学の分野において多くの研究者に よって進められてきた。

清水ら ${ }^{1)}$ はホットフィルム流速計を用いた室内実 験からsweepのレイノルズ応力への寄与が大きく, 植生層内部への高速流体の輸送が顕著であること を示した. Raupach $ら^{2)}$ は風洞実験を行って乱れエネ ルギー収支や組織乱流構造について考察した。 Nepf $ら^{3)}$ はかぶり水深を系統変化させて, 非水没植生と 全水没植生の乱流構造や運動量収支について調べ, 全水没植生流れでは植生層下部の水平輸送が卓越 する領域と植生層上部の鉛直輸送が卓越する領域 の2つに区分されることを明らかにした，池田ら゙は
条件付抽出法を用いて，植生境界部に生じる周期渦 の3次元構造を定量的に把握した. Nepf ら 5 は柔軟な 植生場と純混合層の類似性に着目し, 穂波現象が乱 れの輸送構造に与える影響について調べた。最近で は植生要素の配置や形状と水理特性の関係につい ての研究も行われている. Wilson $5^{6}$ は植生の形状を 2通りに変化させ，葉のついた植生では葉によって 運動量が吸収されることを示した．Carolloら ${ }^{7)}$ は植 生密度を系統的に変化させて柔軟な植生の抵抗と 植生密度の関係を解明した。また襧津ら ${ }^{8)}$ はレーザ 一流速計(LDA)を用いて剛性の高い植生場を対象に 植生の分散効果(dispersive効果)について実験的研究 を行った。

しかしながら，これらの既往研究は点計測による 統計解析が中心で, 植生流れ場の組織構造や渦の挙 動などの瞬間的空間特性については十分な知見が 得られていない。 また植生流れの特性を決める重要

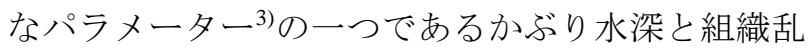
流構造の関係性についても不明な点が多い。これら のことは洪水時の流れの制御や河床形成などに影 響し，適切な河川管理を行ううえで解明することが 必要となる。 そこで本研究では，かぶり水深を系統 


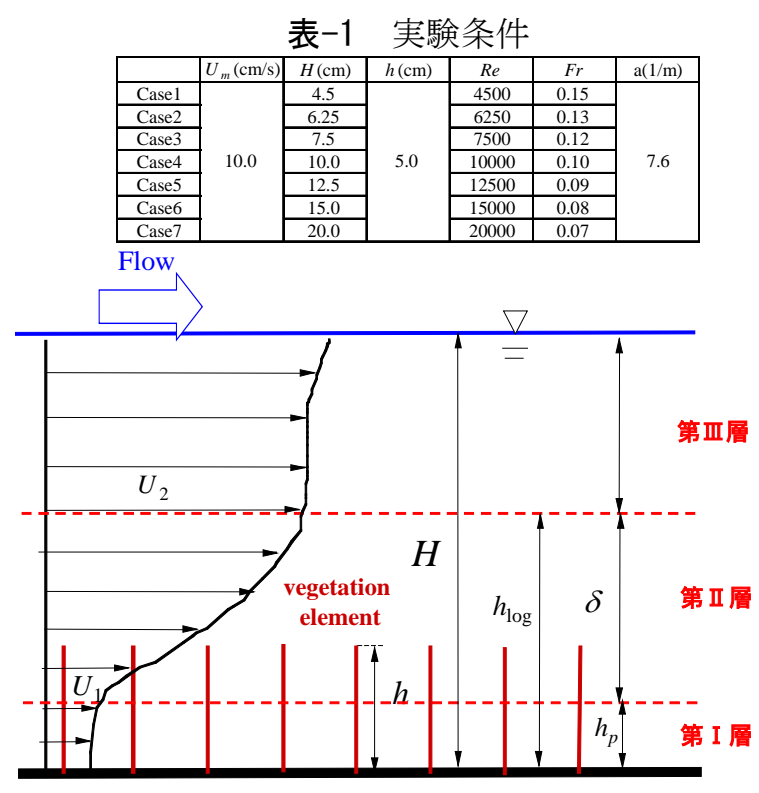

図-1＼cjkstart植生流れの模式図

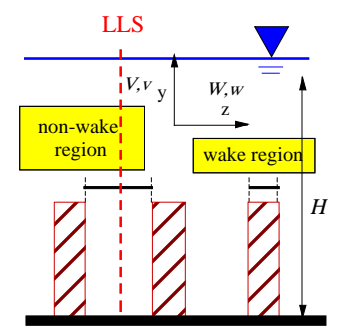

図-2 レーザーの照射位置

変化させて植生開水路流れを対象に高速度カメラ によるPIV解析を行い, かぶり水深と乱流特性や組 織構造の関係について考察する。

\section{2. 流れ場の領域区分}

これまでに得られた多くの研究成果を参考にす ると, 全水没の植生流れは3つの領域に区分され,

模式図を図-1に示寸。第 I 層は非水没植生流れに 類似した特性をもつ底面側の領域で，この領域の上 端をレイノルズ応力の浸透高さ $h_{p}{ }^{3}$ ) とする. 第 II 層 は主流速の鉛直方向変化が大きい混合層に似た領 域である. 図中の $\delta$ は第 II 層の厚さで, この領域で はせん断不安定による組織乱流構造が発生・発達す る. $U_{1}$ と $U_{2}$ は第 II 層を混合層と考えたときの低速 側流速および高速側流速の代表值である. 第III層は 植生の影響が小さく粗面対数則 ${ }^{3}$ が成立する水面側 の領域と定義する. 第III層の下端高さを $h_{\log }$ とする. 本研究の前半ではこのような 3 層の領域区分が有効 であるかをまず検討した。

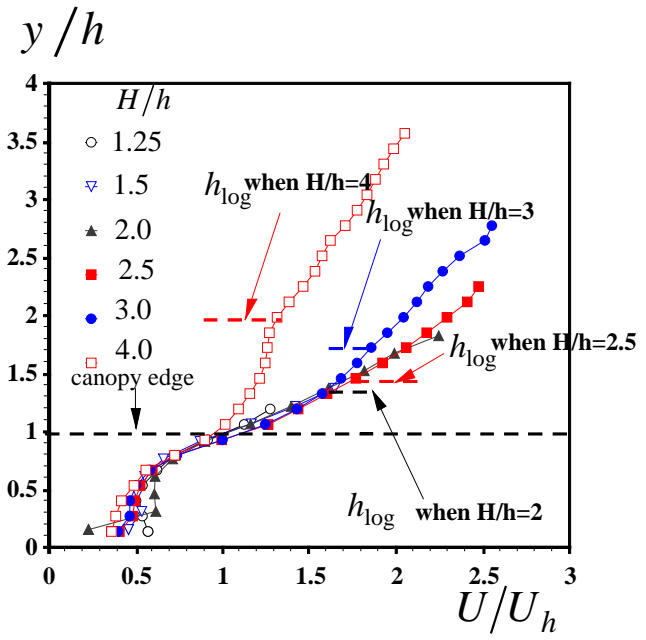

図-3 主流速分布の比較

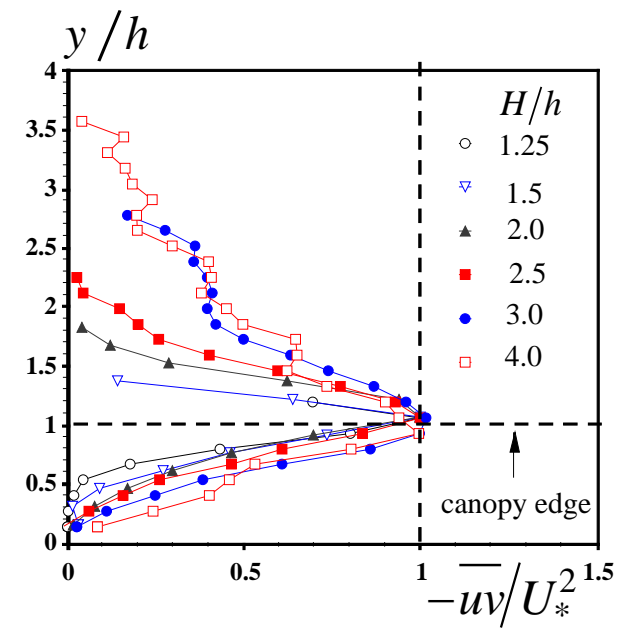

図-4 レイノルズ応力分布の比較

\section{3．実験装置と計測装置}

実験に用いた水路は全長 $10 \mathrm{~m}$, 幅 $40 \mathrm{~cm}$, 高さ $50 \mathrm{~cm}$ の可変勾配型直線水路であり, 前報8) 参照願いた い. $x, y$ および $z$ はそれぞれ, 流下方向, 鉛直方向 および横断方向の座標軸である。 $U, V$ および $W$ は 各方向における時間平均流速成分, $u, v$ おび $w$ は 乱れ変動成分を示寸. $H$ は全水深, $h$ は植生の高さ である，水路底面には，図-1のように計測部を含め て $8 \mathrm{~m}$ の区間にわたって高さ $50 \mathrm{~mm}$, 幅 $8 \mathrm{~mm}$, 厚さ $1 \mathrm{~mm}$ の短冊状の植生模型を正方格子状に配置した. 流下 方向の植生の配置間隔 $L_{v}$, 横断方向の間隔 $B_{v}$ は一 定で $L_{v}=B_{v}=2.4 \mathrm{~cm}$ である. 本研究の植生模型はア クリル製で，沈水性の有茎植物をモデル化したもの で流水による変形や振動はなかった.

乱流計測にはPIV法を用いた. $2 \mathrm{~W}$ 連続アルゴ ンイオンレーザーをシリンドリカルレンズを通し て厚さ $2 \mathrm{~mm}$ のレーザライトシート(LLS)を水路上方 から照射し，水路側方に設置した高速度CMOSカメ ラでデジタル撮影した. 撮影領域のサイズ $(x, y)$ は全 水深領域を含むように $20 \mathrm{~cm} \times 30 \mathrm{~cm}$ 領域で, 流下方向 


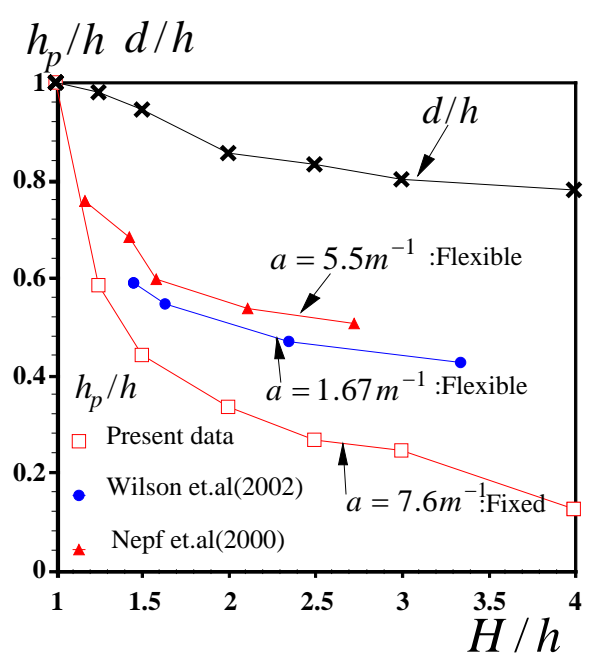

図-5 レイノルズ応力の浸透高さと 原点移動量の比較

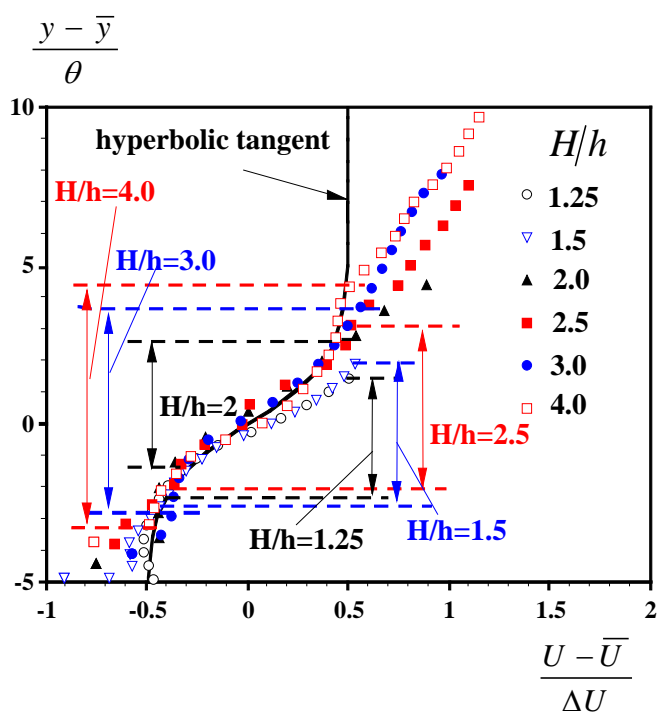

図-6 tanh型流速分布との比較

座標 $x$ の原点 $x=0$ は撮影範囲内にある上流端の植 生要素の位置とした。トレーサーには粒径 $100 \mu \mathrm{m}$, 比重1.02のポリスチレン粒子を用いた. カメラに $100 \mathrm{~Hz}$ の外部トリガーを与えて， $500 \mathrm{~Hz}$ のフレーム レートで 2 枚の連続画像のペアーを45秒間計測し た.すなわちPIV解析に用いる 2 枚の画像の時刻差 は1/500s, 瞬間流速ベクトル $(\tilde{u}, \tilde{v})$ のサンプリング間 隔は1/100sである. 図-2にLLSの横断方向の入射位置 （non- wake面）を示す.

表-1に実験条件を示す. 水理条件は水深 $H$ を非水 没植生のケースから全水没植生のケースまで系統 変化させ, 計7ケースの乱流計測を行った. 断面平 均流速 $U_{m}=10(\mathrm{~cm} / \mathrm{s})$, 植生密度 $a=n A / V_{o}$ は単位体積 当たりの植生の前面遮蔽面積 (frontal area) で $a=7.6\left(m^{-1}\right)$ であり, 全ケースで一定である. 本研 究は大規模な組織乱流構造が発達する植生密度が 比較的小さい状況を想定している.
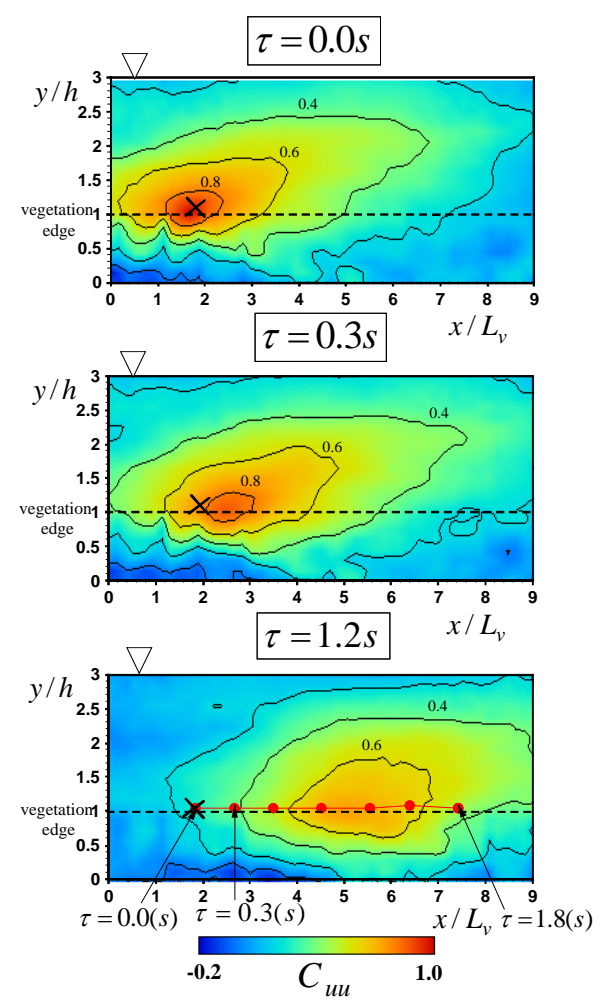

図-7 時空間相関解析

\section{4. 実験結果と考察}

\section{(1) 平均流特性と乱れ特性}

図-3に全ケースについて時間平均した主流速 $U$ の分布を比較した. $U$ の值は植生先端 $(y=h)$ におけ る主流速の值 $U_{h} \equiv U(y=h)$ で無次元化している. 全 ケースで植生先端付近の第 II 層で流速シアー $\partial U / \partial y$ が大きくなり, 植生内部 $(y / h<1)$ で流速が一 定流速 $U_{1}$ に近い值をとる領域 (第 I 層) が存在して いる. 図中にはかぶり水深領域 $(y / h>1)$ の主流速 $U$ と粗面対数則分布を比較して評価した第III層の下 端高さ $h_{\log }$ を図示した. 水深が大きくなると $h_{\log }$ は 増加し，第III層の厚さが大きくなるのがわかる.

図-4に全ケースのレイノルズ応力 $-\overline{u v} / U_{*}^{2}$ の分布 を示す. 摩擦速度 $U$ *は植生先端でのレイノルズ応力 のピーク值とした ${ }^{8)}$. 水深が増加するとレイノルズ 応力が植生内部に浸透して大きくなる特性がみら れる。この特性を定量評価するためにNepf ら ${ }^{3)}$ はレ イノルズ応力の浸透高さ $h_{p}$ を植生内部でレイノル ズ応力のピーク值の $10 \%$ となる高さで定義した. 図 -5に本実験值の $h_{p}$ を同様の手法で算出した既往研 究 ${ }^{33)}$ () 結果と比較して示す. なお, 既往研究はいず れも可動変形する植生モデルを用いた室内実験で ある. $h_{p}$ はかぶり水深が増加すると減少しており既 往研究の傾向と定性的に一致する. 本研究の結果は 既往研究と比較して植生密度が大きいにも関わら ず，全体的にこれらの結果よりも小さい值をとり， 

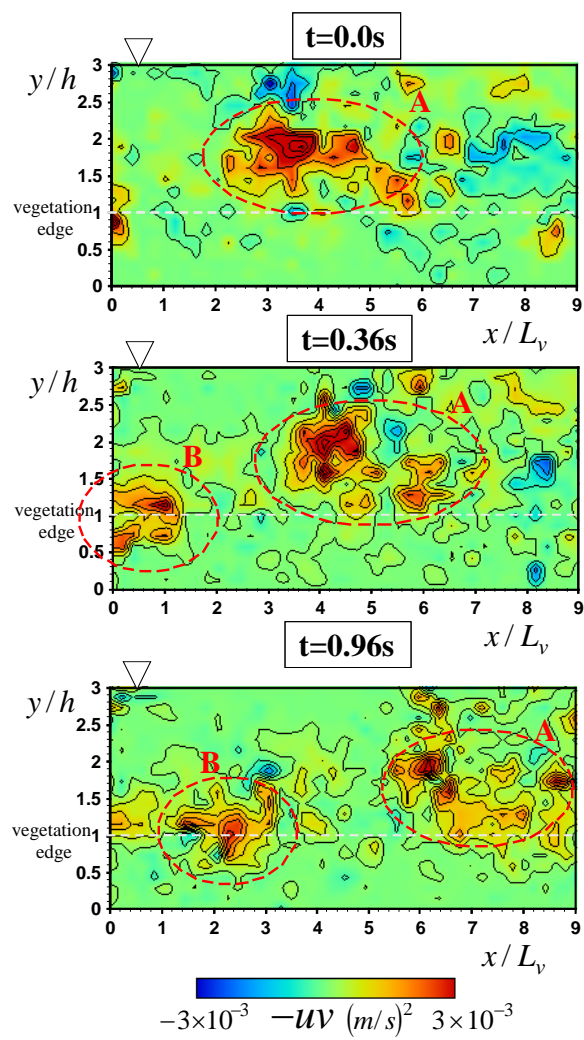

図-8 瞬間レイノルズ分布

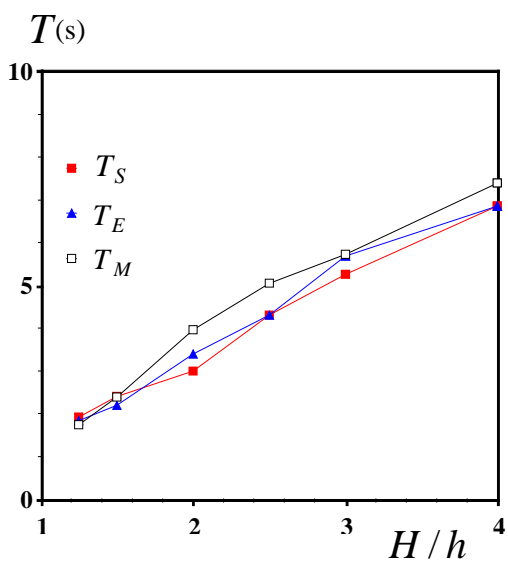

図-10 sweep, ejection $の$ 周期比較

より多くの運動量が植生内部に輸送されることが わかる。これは既往研究では植生が振動するために 輸送エネルギーが植生の変形にも消費されるため と思われ興味深い. 第吕層で成立する粗面対数則の 原点移動量 $d$ も図-5に併記したが, $h_{p}$ と同様に水深 が増大寸ると減少する。これはかぶり水深の増加と ともに植生の粗面としての効果が小さくなること を意味している.

次に植生先端付近の第 II 層(図-1) と混合層の類似 性について検討するために，図-6に混合層で成立す るhyperbolic tangent型の流速分布と比較した. 混合層 型の流速分布は次式で近似される ${ }^{3)}$.

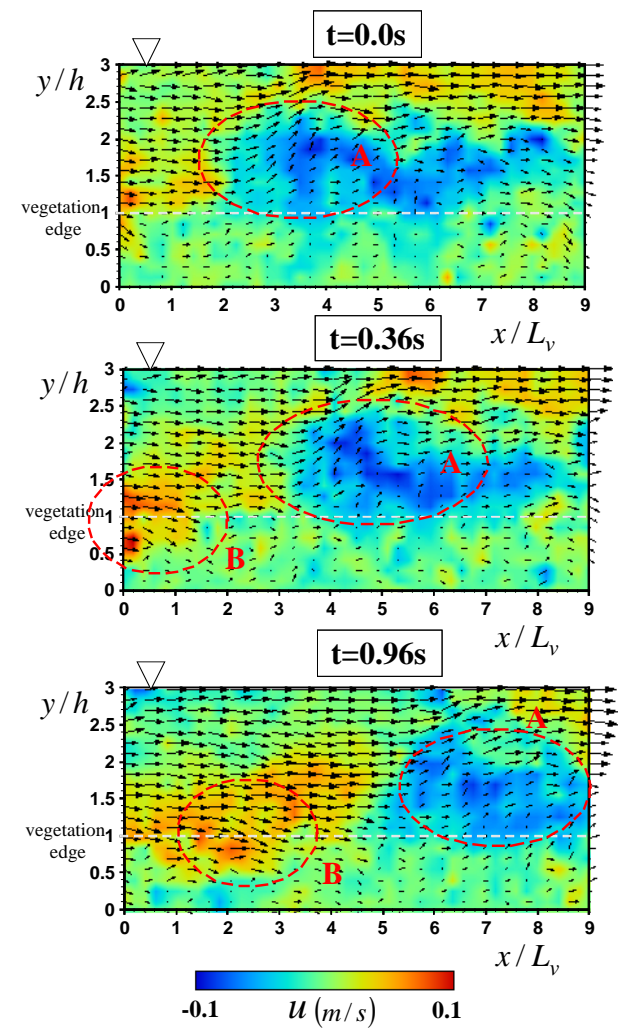

図-9 瞬間ベクトル分布

$$
\frac{U-\bar{U}}{\Delta U}=\frac{1}{2} \tanh \left(\frac{y-\bar{y}}{2 \theta}\right)
$$

ここで $\bar{U}=1 / 2\left(U_{1}+U_{2}\right), \Delta U=U_{2}-U_{1}, \theta$ は運動量 厚さで流れ場から決定される. 高速側主流速 $U_{1}$ は第 II 層と第III層の境界高さ $y=h_{\log }$ での流速值, 低速側 主流速 $U_{2}$ は運動量の浸透高さ $y=h_{p}$ での流速值, 混合層の中心 $\bar{y}$ は $\bar{y}=\left(h_{\log }+h_{p}\right) / 2$ とした.

図中には各ケースの $h_{\log }, h_{p}$ を破線で併示した。 いずれのケースも第 II 層では式(1)の曲線に近い分 布をもつ。 またかぶり水深が大きいほど混合層厚 $\delta$

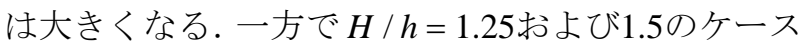
では植生による粗面効果が大きくなり, 混合層型分 布との類似性は弱くなることがわかる.

\section{(2) 時空間相関特性}

図-7に $H / h=3.0$ のケースの時空間相関コンター を示す.ここで時空間相関係数 $C_{u u}$ は次式で定義さ れる。

$$
C_{u u}=\frac{\overline{u\left(x_{0}, y_{0}, t_{0}\right) u\left(x_{0}+\Delta x, y_{0}+\Delta y, t_{0}+\tau\right)}}{u^{\prime}\left(x_{0}, y_{0}\right) u^{\prime}\left(x_{0}+\Delta x, y+\Delta y\right)}
$$

ここで $\left(x_{0}, y_{0}, t_{0}\right)$ は時間 $t_{0}$ における固定点の座標で, $\left(x_{0}+\Delta x, y_{0}+\Delta y, t_{0}+\tau\right)$ は遅れ時間 $\tau$ における移動点 の座標, $u^{\prime}\left(x_{0}, y_{0}\right)$ は乱れ強度である.

図-7は植生先端の点を基準点とした時空間相関 $C_{u u}$ でそれぞれ遅れ時間 $\tau=0.0,0.3,1.2(\mathrm{~s})$ を表してい 


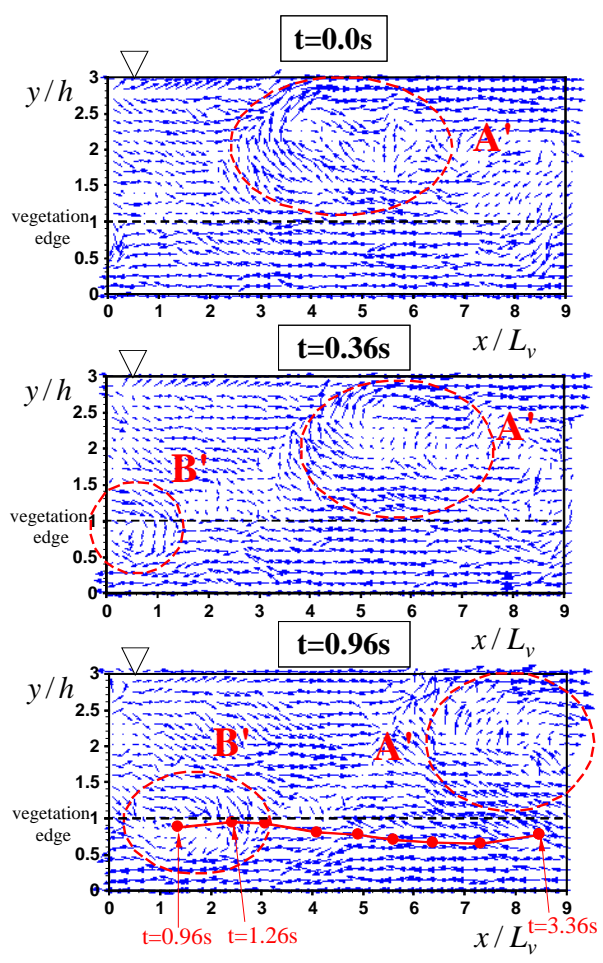

図-11 組織渦の抽出

る. $\tau=0.0(\mathrm{~s})$ の図より植生先端付近に組織構造が存 在することがわかる. $\tau=0.3(\mathrm{~s})$ において相関のピー ク值が流下方向に移動しており, 組織構造が流下方 向に移流されていることが確認できる. 0.3(s)ごとに 相関のピーク位置を追跡したものを $\tau=1.2(\mathrm{~s})$ の図中 に示した。これより組織構造が植生先端付近をほぼ 一定の流速で移流されているのが観察された.

\section{(3) 組織乱流構造について}

図-8および図-9はそれぞれ $H / h=3.0$ のケースに おける瞬間レイノルズ応力 $-u v$ の分布と瞬間ベクト ル $(\tilde{u}, \tilde{v})$ の分布を時系列的に示したもので, 同時刻 のものを対応させている. 図-9中には乱変動成分 $u$ のコンターをカラー表示した. $t=0(\mathrm{~s})$ では図-8で 植生層外部(破線部 $\mathrm{A})$ において $-u v$ の局所的に大き な正值分布がみられる. 図-9では破線部Aの領域で $u<0$ となり，低速流の上昇べクトルである ejection $(u<0, v>0)$ が発生しているのがわかる. $t=0.36(\mathrm{~s})$ ではejectionが流下方向に移流されている. またその上流側において植生層内部(破線部B)で $-u v$ の大きな正值分布がみられる. Bでは $u>0$ とな り, 高速流の下降ベクトルである $\operatorname{sweep}(u>0, v<0)$ が発生している. $t=0.36(\mathrm{~s}) て ゙ は$ てejection, sweepはと もに流下方向に移流されている。このことから瞬間 レイノルズ応力が大きな正值をとる領域は大規模 な組織乱流構造の発生と対応している. また図-7で 考察した組織構造はejection, sweepが交互に発生す

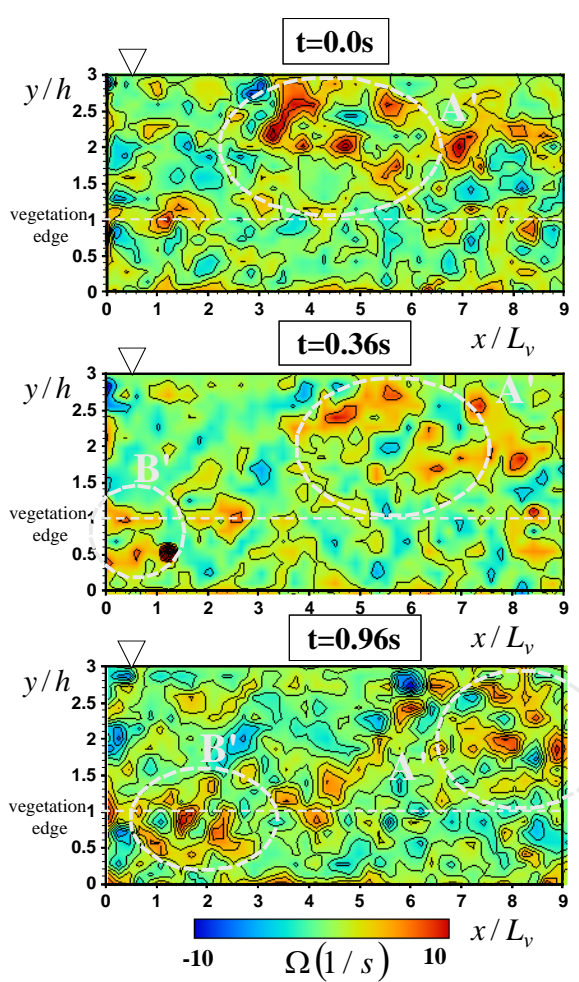

図-12 瞬間渦度分布

るような組織変動サイクルをもつことがわかった。

図-10に全ケースについて植生先端部における sweep, ejectionの発生周期 $T_{S}, T_{E}$ と混合層の渦周期 $T_{M}$ を比較したものである. sweep, ejectionの発生周 期は瞬間レイノルズ応力と瞬間ベクトル分布から 発生したsweepおよびejectionの数をカウントして算 出した。 混合層の渦周期 $T_{M}$ は次式で与えられる最 大発達率 $f=1 / T_{M}$ から計算される ${ }^{3)}$.

$$
\frac{f \theta}{\bar{U}}=0.032
$$

図より sweep, ejectionの発生周期 $T_{S}, T_{E}$ は全ケー スでほぼ等しく, 水深が大きくなると周期が長くな る傾向がみられた。これらの周期は混合層の周期 $T_{M}$ に近い值をもち，このことからも植生流れと混 合層のアナロジーがうかがえる.

\section{(4) 植生流れ場の組織渦構造について}

Adrian ${ }^{99}$ の手法に従って組織渦構造の抽出を試み る. 図-11は図-9 と同時刻の局所主流速 $\tilde{u}$ から植生 先端 $(y=h)$ の移流速度 $U_{c}(h)$ を引いた移動座標系の 瞬間ベクトル分布を時系列的に示したものである。 ここで移流速度 $U_{c}(h)$ は時空間相関解析から計算し ている。また図-12には図-11と同時刻の瞬間渦度分 布を示した. $t=0(\mathrm{~s})$ でejectionの発生域(破線部A') において瞬間べクトルが渦状になっており, 図-12 の渦度分布でもこの領域で大きな正值をとること から, 植生先端の移流速度 $U_{c}(h)$ を引くことで植生 


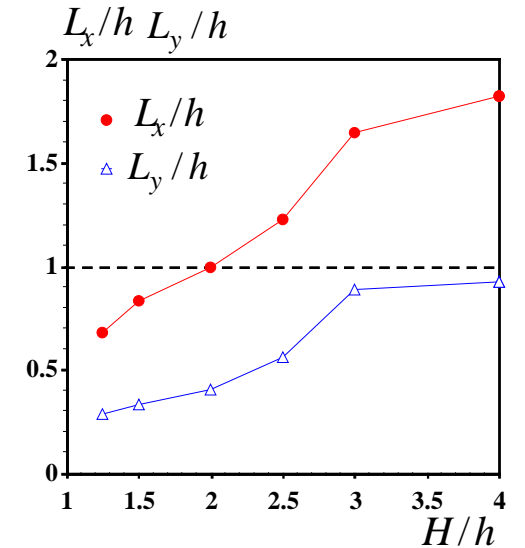

図-13 植生先端部の渦の長さスケールの比較

層外部で閉じた渦状の組織渦を抽出できたといえ る. $t=0.36(\mathrm{~s})$ では破線部A'の渦が流下方向に移流 されている.また上流側のsweep発生域(破線部B') において瞬間ベクトルが渦状になっていて, 渦度分 布でもこの領域で局所的に大きな正值をとること から植生先端付近で植生内部に入りこむ渦といえ る. このことから瞬間レイノルズ応力の極值分布か ら判定されたsweep, ejectionが組織渦を形成してい ることが確認される。 なお はほぼ一致している. 図-11の $t=0.96(\mathrm{~s}) て ゙ は$ 破線部 A',B'の渦がともに流下方向に移流されている. $t=0.96(\mathrm{~s})$ の図には渦中心を渦度のピーク位置と仮 定して破線部B'の渦の挙動を0.3(s) ごとに追跡した ものを示した．植生先端にあった渦が植生内部に入 り込む様子が観察される. また図-11で抽出した渦 構造は図-8の-uvの正值分布にも対応することから， 組織渦が植生流れの運動量輸送に寄与していると 考えられる.

PIV計測では渦の流下方向と鉛直方向の長さスケ 一ル $L_{x}, L_{y}$ は次式から求めることができる.

$$
\begin{aligned}
& L_{x}=\int_{0}^{\infty} \frac{\overline{u\left(x_{0}, y_{0}, t_{0}\right) u\left(x_{0}+x, y_{0}, t_{0}\right)}}{u^{\prime}\left(x_{0}, y_{0}\right) u^{\prime}\left(x_{0}+x, y_{0}\right)} d x \\
& L_{y}=\int_{0}^{\infty} \frac{\overline{u\left(x_{0}, y_{0}, t_{0}\right) u\left(x_{0}, y_{0}+y, t_{0}\right)}}{u^{\prime}\left(x_{0}, y_{0}\right) u^{\prime}\left(x_{0}, y_{0}+y\right)} d x
\end{aligned}
$$

図-13に植生先端部における渦の長さスケール $L_{x}$, $L_{y}$ を全ケースについて比較した. 全ケースにおいて $L_{x} / L_{y}>1$ となり植生先端部で長円形の渦が生成さ れていると考えられる. $L_{x}, L_{y}$ はともに水深が増大 すると増加しており, かぶり水深が大きくなるほど 大スケールの渦が発達する. また $L_{y}$ が $L_{y} / h=1$ 程 度に収束するため, 植生先端部での渦の鉛直方向の 長さスケールは水深が増加しても植生の長さスケ 一ル $h$ 程度で一定值に達すると予測され, 森林植生 での渦スケール2)に一致するものと考えられる。

\section{5. 結論}

本研究では水深を系統変化させて開水路植生流 れを対象にPIV計測を行い, 乱流構造や組織構造の 瞬間特性に及ぼすかぶり水深の影響について考察 した。 以下に得られた知見を示す。

1）レイノルズ応力の浸透高さ $h_{p}$ の比較から, かぶ り水深が大きくなると運動量が植生層のより深 くまで浸透することが示された。

2) 植生先端部での組織構造の瞬間特性や周期特性 について調べ, 植生先端付近の流れ場は混合層 と良く似た性質を示す。

3）渦構造の瞬間特性について考察し, 組織渦構造 はsweep, ejectionの発生と関係があり運動量輸送 に寄与していることがわかった。

4）組織構造の周期特性や渦の長さスケールから水 深が増加すると大規模な組織構造が発達する。

\section{参考文献}

1）清水義彦・辻本哲郎 - 中川博次 - 北村忠紀 : 直立性植 生層を伴う流れ場の構造に関する実験的研究, 土木学 会論文集，第438号，pp.31-40，1991.

2) Raupach, M. R., Finnigan, J.J. and Brunet, Y: Coherent Eddies and Turbulence in Vegetation Canopies: The Mixing-Layer Analogy, Boundary-Layer Meteorology., Vol.78, pp.351-382, 1996.

3) Nepf, H. M. and Vivoni, E. R. : Flow Structure in Depth-limited, Vegetated Flow, J. of Geophysical Res., Vol. 105, pp.28547-28557, 2000.

4) 池田祐一, 金成修一, 須賀克三 : 条件付抽出法 による側岸部植生境界における組織乱流構造の 3 次元構造の基礎的研究, 水工学論文集, 第 45 巻, 土木学会, pp.853-858, 2001.

5) Ghisalberti, M. and Nepf, H. M. : Mixing Layers and Coherent Structures in Vegetated Aquatic Flows, J. of Geophysical Res., Vol. 107, pp.3-1 - 3-11, 2002.

6) Wilson, C.A.M.E, Stoesser, T., Bates, P.D. and Batemann Pinzen, A.: Open Channel Flow through Different Forms of Submerged Flexible Vegetation, J. of Hydraulic Engineering, Vol. 129, pp.847-853, 2003.

7) Carollo, F.G., Ferro, V. and Termini, D.: Flow Resistance Law in Channel with Flexible Submerged Vegetation, $J$. of Hydraulic Engineering, Vol. 131, pp.554-564, 2005.

8）襧津家久・山上路生・岡本隆明：植生キャノピー開 水路流れの乱流構造とディスパーシブ効果に関す る実験的研究, 水工学論文集第 50 巻, 土木学会, pp.1135-1140, 2006.

9) Adrian, R.J., Meinhart, C.D. and Tomkins, C.D.: Vortex Organization in the Outer Region of the Turbulent Boundary Layer, J. of Fluid Mech, Vol. 422, pp.1-54, 2000.

(2007.9.30受付) 